\author{
Acta Scientifica Naturalis \\ Former Annual of Konstantin Preslavsky University - Chemistry, Physics, Biology, Geography \\ Journal homepage: http://www.shu.bg
}

Received: 30.10 .2016

Accepted: 11.01.2017

\title{
Allelopathic activity of Nepeta nuda L. subsp. nuda water extracts
}

\author{
Asya Dragoeva $^{1}$, Zheni Stoyanova ${ }^{1}$, Vanya Koleva ${ }^{1}$, Daniela Dragolova ${ }^{2}$ \\ ${ }^{1}$ Department of Biology, Faculty of Natural Sciences, "K. Preslavsky” University, 115 Universitetska Str., \\ 9712 Shumen, Bulgaria \\ ${ }^{2}$ Sofia University, Faculty of Biology, 8 "Dragan Tsankov" Blvd., 1421 Sofia, Bulgaria \\ e-mail: jenidim@shu-bg.net
}

\begin{abstract}
Nepeta nuda subsp. nuda is a medicinal plant growing wild in Bulgaria. Different species of Nepeta genus have been reported to possess allelopathic potential. The present study was conducted to observe its phytotoxic effects on T. aestivum and C. sativus L. seeds in laboratory conditions. Nepeta water extracts (NWE) prepared from aerial parts of plants at concentrations 2, 4, 6, 8, 10, 12 and $14 \mathrm{~g} / \mathrm{l}$ were tested. The rate of seed germination, the root and shoot length, fresh and dry weight of seedlings were observed after treatment with NWE. As a control served seeds treated with distilled water. Germination was not affected, but NWE showed deterioration in seedling growth. Roots were more affected than shoots. The fresh and dry weights were reduced upon treatment with the extracts tested. These negative effects were dose-dependent. The overall results indicate presence of water soluble allelochemicals in Nepeta nuda subsp. nuda.
\end{abstract}

Keywords: Nepeta nuda subsp. nuda, allelopathy, root and shoot growth inhibition, fresh and dry weight.

\section{Introduction}

Secondary metabolites in plants have drawn great attention due to increasing public concern against synthetic agrochemicals $[1,2,3]$. Different medicinal plants from Lamiaceae family have been studied for their allelopatic potential. Allelopathy of essential oils has been documented $[4,5,6,7]$. There are also data on presence of water soluble substances in plant tissues $[8,9,10]$. The effects of allelochemicals on sensitive plants can easily be tested in laboratory conditions: plants` responses such as changes in seed germination, plant height and root length, dry and fresh weight are estimated [1].

The genus Nepeta (Lamiaceae) includes approximately 250 species [11]. Various valuable constituents have been found in Nepeta essential oils - nepetalactones, germacrene D, $\beta$-caryophyllene; camphor, cineole, borneol, camphene etc. [12, 13, 14, 15]. Essential oil composition of Nepeta genus exhibits significant variations according to the geographic region, climatic conditions, time of plant collection etc. [15]. Different species of Nepeta genus are reported to possess some biological activity and are used in folk medicine $[16,17]$. Allelopathic potential of this genus was also revealed. Phytotoxicity of Nepeta essential oils has been mainly tested [18, 19, 20, 21, 22, 23, 24]. Allelopathy of water extracts has been studied by very few authors $[25,26]$.

Nepeta nuda subsp. nuda L. (syn. Nepeta pannonica L.) is a valuable medicinal plant widespread in Europe $[12,27]$. This plant is growing wild in Bulgaria [28]. To the best of our knowledge, there are no studies on phytotoxicity of Nepeta nuda subsp. nuda water extracts.

The aim of this study was to evaluate the allelopathic activity of water extracts made from the aerial parts of Nepeta nuda subsp. nuda in laboratory conditions using: 1) germination and root/shoot elongation and 2) fresh and dry weight assays.

\section{Materials and methods}

46

Corresponding author: jenidim@shu-bg.net DOI: 10.1515/asn-2017-0007 


\subsection{Plant material}

Aerial parts of plants cut about $30 \mathrm{~cm}$ from the top were collected in the summer of 2014 near Sofia and dried at room temperature. For allelopathic studies, seeds of Cucumis sativus L. cv. Gergana and Triticum aestivum L. cv. GTW were used.

2.2. Plant extracts. The air-dried and finely ground aerial parts of Nepeta nuda subsp. nuda were placed in distilled water and left to stay for $24 \mathrm{~h}$ at room temperature. The nepeta water extracts (NWE) were then filtered through filter paper. The test extracts were prepared at concentrations 2, 4, 6, 8, 10, 12 and $14 \mathrm{~g} / \mathrm{l}$.

2.3. Phytotoxicity testing. Twenty seeds of $C$. sativus and $T$. aestivum, respectively, were placed on filter paper in each of Petri dishes $(11 \mathrm{~cm}$ in diameter). $5 \mathrm{ml}$ of each extracts or distilled water, as a control, was applied to the seeds. The dishes were sealed and incubated at $25 \pm 1^{\circ} \mathrm{C}$ for $72 \mathrm{~h}$. Three replications of each treatment were done.

Germination assay. Germination was determined by counting the number of germinated seeds. Final germination was expressed as percentage after statistical analyses were performed on the raw data.

Root/shoot elongation assay. The length of the roots and shoots of germinated seeds was measured. Seeds that did not germinate were not included in the test.

Fresh and dry weights assay. The fresh weight of seedlings was determined and the averages were calculated. To measure the dry weight, the seedlings were oven dried at $75^{\circ} \mathrm{C}$ until a constant weight was obtained. In this experiment, the total weight of the seedling has been considered as the seedling weight.

\subsection{Statistical analysis}

Experimental data were processed by Student's t-test.

\section{Results and discussion}

Germination assay. Allelopathic effect of NWE on germination percentage of T. aestivum L. and $C$. sativus $\mathrm{L}$. is shown in Table 1 . The inhibition of wheat germination by the extracts ranged from $0 \%(4 \mathrm{~g} / \mathrm{l})$ to $26 \%$ (14 g/l). There was no clear dose-dependent effect: treatment with $2 \mathrm{~g} / \mathrm{l}$ inhibited germination by $7.41 \%$, but $4 \mathrm{~g} / \mathrm{l}$ had no effect. Similarly the negative influence of $8 \mathrm{~g} / \mathrm{l}$ was stronger than $10 \mathrm{~g} / \mathrm{l}$.

Water extracts had no signifficant effect on germination of cucumber seeds. A nonlinear effect also has been observed: the lowest concentration inhibited germination by $6.9 \%$ and the highest concentration - by $1.72 \%$.

Table 1. Effect of NWE on germination of T. aestivum L. and C. sativus L. seeds

\begin{tabular}{clc}
\hline NWE, g/l & T. aestivum, $\%$ & C. sativus, $\%$ \\
\hline $0 \mathrm{~g} / \mathrm{l}$ & $90.00 \pm 0$ & $96.67 \pm 0.58$ \\
$2 \mathrm{~g} / \mathrm{l}$ & $83.33 \pm 0.58^{*}$ & $90.00 \pm 1.73$ \\
$4 \mathrm{~g} / \mathrm{l}$ & $90.00 \pm 1.00$ & $93.33 \pm 1.53$ \\
$6 \mathrm{~g} / 1$ & $85.00 \pm 1.73$ & $90.00 \pm 1.73$ \\
$8 \mathrm{~g} / \mathrm{l}$ & $81.67 \pm 0.58^{* *}$ & $91.67 \pm 1.53$ \\
$10 \mathrm{~g} / 1$ & $85.00 \pm 1.00$ & $93.33 \pm 1.53$ \\
$12 \mathrm{~g} / 1$ & $81.67 \pm 1.53^{* *}$ & $90.00 \pm 2.00$ \\
$14 \mathrm{~g} / 1$ & $66.67 \pm 1.15^{* *}$ & $95.00 \pm 1.00$ \\
\hline
\end{tabular}

Data are expressed as means \pm SD (standard deviation),

$* \mathrm{P} \leq 0.05, * * \mathrm{P} \leq 0.01 ; \mathrm{NWE}-$ Nepeta water extracts.

The results presented in Table 1 revealed that water soluble allelochemicals in Nepeta nuda have no significant influence on seed germination. The germination of wheat seeds was more affected than cucumber seeds. Moreover, the nonlinear effect was established. The inconsistent effects of extracts tested on germination are in accordance with data about Nepeta meyeri Benth. water extracts [25]. It is known that plant interaction is a complex phenomenon and even positive and negative effects could be observed at different concentrations of secondary metabolites $[25,10]$.

Root/shoot elongation assay. NWE influenced significantly the growth of test species (Figures 1 and 2). The root and shoot lengths of 3-day-old treated seedlings of both species were much lower in comparison to the control. Unlike the germination, seedlings growth was affected in dose dependent manner.

47

Corresponding author: jenidim@shu-bg.net

DOI: 10.1515/asn-2017-0007 
ASN, Vol 4, No 1, Pages 46-51, 2017

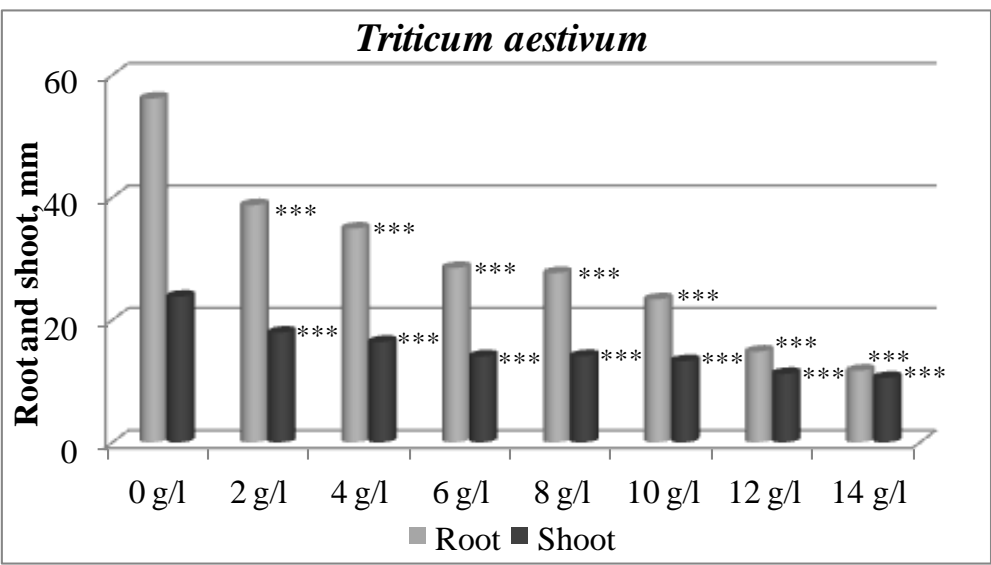

Figure 1. Effect of water extracts of Nepeta on root and shoot lenght of T. aestivum L.; *** $\mathrm{P} \leq 0.001$.

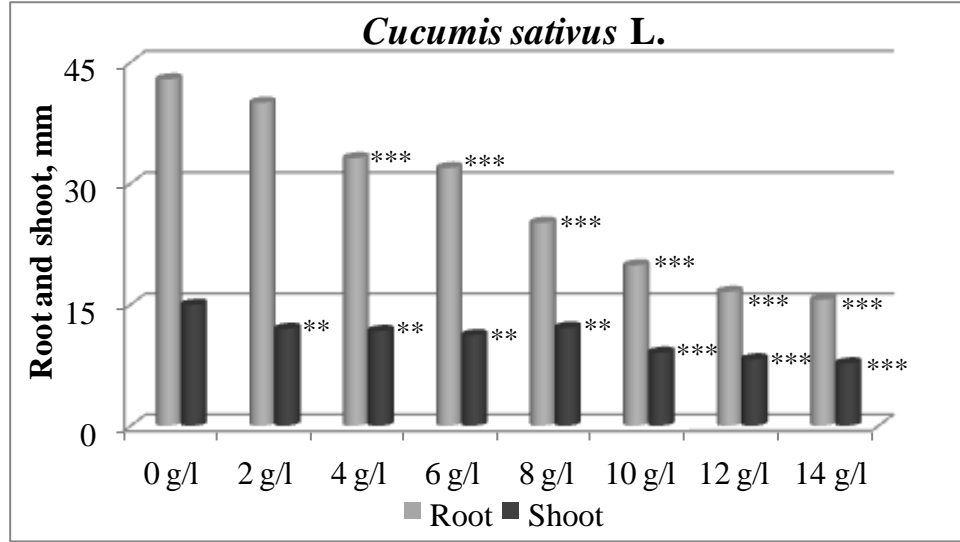

Figure 2. Effect of water extracts of Nepeta on root and shoot lenght of C. sativus L.; **P $\leq 0.01, * * * \mathrm{P} \leq$ 0.001 .

With all treatments, the lengths of roots showed more inhibition than the lengths of shoots. The inhibition of wheat root elongation by the extracts ranged from $31 \%(2 \mathrm{~g} / \mathrm{l})$ to $79 \%(14 \mathrm{~g} / \mathrm{l})$ and shoot elongation ranged from $25 \%(2 \mathrm{~g} / \mathrm{l})$ to $56 \%(14 \mathrm{~g} / \mathrm{l})$. The inhibition of cucumber root elongation by the extracts ranged from $7 \%(2 \mathrm{~g} / \mathrm{l})$ to $64 \%(14 \mathrm{~g} / \mathrm{l})$, and shoot elongation ranged from $20 \%(2 \mathrm{~g} / \mathrm{l})$ to $48 \%(14 \mathrm{~g} / \mathrm{l})$.

Germination is widely used parameter to detect the phytotoxicity, but the results of present study revealed that early seedling growth is influenced to great degree by extracts tested. Similar to our study, several researchers have reported that seedling growth is more sensitive to allelochemicals than germination $[29,30,31]$. When compared to the control, root growth was more inhibited than that of the shoots. Stronger inhibitory effect on root length as compared to shoot length was observed in other studies [32,33]. A possible explanation is that direct contact of the roots with the filter paper leads to constant absorption of the water extract [34]. According to [35] the permeability of allelochemicals to root is greater than to shoot. Obviously, the root length reduction is a better indicator of allelopathic effect than shoot growth [36].

In comparative analysis between two test objects, $T$. aestivum were more sensitive to extracts tested than $C$. sativum. This observation confirmed other data that $T$. aestivum is appropriate test object in toxicity assays $[37,38]$.

Fresh and dry weights assay. As described by [1]: "Plant exposed to natural products can suffer modifications in pattern of biomass allocations between organs, rates of plant growth, water content and relative water content. These parameters are gravimetrically estimated through the dry and fresh weight of plant organs". The fresh weight (FW) and dry weight (DW) of 3-day old seedlings of both test objects were affected upon treatment with NEW (Tables 2 and 3). Both the FW and DW of treated seedlings were reduced

48 
ASN, Vol 4, No 1, Pages 46-51, 2017

in comparison to the control. These negative effect was dose-dependent. Similarly to growth inhibition, wheat seedlings were more sensitive than cucumber seeds.

Table 2. Fresh and dry weight of T. aestivum L.

\begin{tabular}{clc}
\hline Concentrations of & \multicolumn{2}{c}{ Weight, g } \\
\cline { 2 - 3 } NWE & \multicolumn{1}{c}{ Fresh } & Dry \\
\hline $0 \mathrm{~g} / \mathrm{l}$ & $2.11 \pm 0.20$ & $0.76 \pm 0.12$ \\
$2 \mathrm{~g} / \mathrm{l}$ & $1.61 \pm 0.18^{*}$ & $0.74 \pm 0.25$ \\
$4 \mathrm{~g} / 1$ & $1.67 \pm 0.21$ & $0.72 \pm 0.11$ \\
$6 \mathrm{~g} / 1$ & $1.38 \pm 0.23^{* *}$ & $0.67 \pm 0.09$ \\
$8 \mathrm{~g} / 1$ & $1.35 \pm 0.06^{* *}$ & $0.68 \pm 0.09$ \\
$10 \mathrm{~g} / 1$ & $1.37 \pm 0.02^{* *}$ & $0.67 \pm 0.11$ \\
$12 \mathrm{~g} / 1$ & $1.19 \pm 0.18^{* *}$ & $0.56 \pm 0.02^{*}$ \\
$14 \mathrm{~g} / 1$ & $1.10 \pm 0.14^{* *}$ & $0.51 \pm 0.01^{*}$ \\
\hline
\end{tabular}

Data are expressed as means $\pm \mathrm{SD}$ (standard deviation), $* \mathrm{P} \leq 0.05, * * \mathrm{P} \leq 0.01 ; \mathrm{NWE}-$ Nepeta water extracts.

Table 3. Fresh and dry weight of $C$. sativus L.

\begin{tabular}{ccc}
\hline Concentrations of & \multicolumn{2}{c}{ Weight, g } \\
\cline { 2 - 3 } NWE & Fresh & Dry \\
\hline $0 \mathrm{~g} / 1$ & $2.01 \pm 0.12$ & $0.56 \pm 0.24$ \\
$2 \mathrm{~g} / 1$ & $1.96 \pm 0.31$ & $0.51 \pm 0.12$ \\
$4 \mathrm{~g} / 1$ & $1.81 \pm 0.54$ & $0.47 \pm 0.04$ \\
$6 \mathrm{~g} / 1$ & $1.84 \pm 0.30$ & $0.46 \pm 0.08$ \\
$8 \mathrm{~g} / 1$ & $1.75 \pm 0.56$ & $0.41 \pm 0.02$ \\
$10 \mathrm{~g} / 1$ & $1.71 \pm 0.26$ & $0.41 \pm 0.04$ \\
$12 \mathrm{~g} / 1$ & $1.63 \pm 0.29$ & $0.39 \pm 0.10$ \\
$14 \mathrm{~g} / \mathrm{1}$ & $1.54 \pm 0.35$ & $0.37 \pm 0.09$ \\
\hline
\end{tabular}

Data are expressed as means \pm SD (standard deviation; NWE - Nepeta water extracts.

\section{Conclusion}

The results of present study revealed that Nepeta nuda subsp. nuda has allelopathic effect on the growth and development of T. aestivum L.and C. sativus L. Water soluble allelochemicals inhibited the seedling growth and reduced the fresh and dry weights of the tested plant species. These negative effects were dose dependent. Germination was not affected by water extracts. Further research is needed to identify specific allelochemicals presented in Nepeta nuda subsp. nuda.

\section{Acknowledgments}

This work has been supported by the Bulgarian Ministry of Education and Science, grant no. RD-08266/10.03.2015 and grant no. RD-08-271/11.03.2015.

\section{References}

[1]. Sampietro, D.A.; Quiroga, E.N.; Soberón, J.R.; Sgariglia, M.A.; and Vattuone, M.A., Bioassays with Whole Plants and Plant Organs. In: Sampietro, D. A.; Catalan, C. A. N.; Vattuone, M. A., Eds. Isolation, Identification and Characterization of Allelochemicals/Natural Products. Science Publishers, Enfield, NH, USA, 2009.

49 
[2]. Duke, S.O., Allelopathy: Current Status of Research and Future of the Discipline: A Commentary, Allelopathy Journal. 2010, 25, 17-30.

[3]. Bhadoria, P.B.S., Allelopathy: A Natural Way towards Weed Management, American Journal of Experimental Agriculture. 2011, 1, 7-20.

[4]. Arminante, F.; De Falco, E.; De Feo, V.; De Martino, L.; Mancini, E.; Quaranta, E., Allelopathic activity of essential oils from mediterranean Labiatae, ISHS Acta Hort. 2006, 723, 347-356.

[5]. Azirak, S.; Karaman, S., Allelopathic effect of some essential oils and components on germination of weed species, Acta Agriculturae Scandinavica. 2008, 58(1), 88-92.

[6]. De Almeida, L.F.R.; Frei, F.; Mancini, E.; De Martino, L.; De Feo, V., Phytotoxic activities of Mediterranean essential oils, Molecules. 2010, 15, 4309-4323.

[7]. Dhima, K.; Vasilakoglou, I.; Garane, V.; Ritzoulis, Ch.; Lianopoulou, V.; Panou-Philotheou, E., Competitiveness and Essential Oil Phytotoxicity of Seven Annual Aromatic Plants, Weed Science. 2010, $58,457-465$.

[8]. Economou, G.; Travlos, I.S.; Folinas, A.; Karamanos, A.J., Greek oregano (Origanum vulgare ssp. hirtum) as allelopathic plant, J. Food Agriculture \& Environment. 2007, 5, 348-351.

[9]. Dhima, K.V.; Vasilakoglou, I.B.; Gatsis, T.D.; Panou-Philotheou, E.; Eleftherohorinos, I.G., Effects of aromatic plants incorporated as green manure on weed and maize development, Field Crop Res, 2009, $110,235-241$.

[10]. Baeshen, A. Ali., Morphological and elements constituent effects of allelopathic activity of some medicinal plants extracts on Zea mays, Int.J.Curr.Res.Aca.Rev. 2014, 2(4), 135-145.

[11]. Kofidis, G.; BOSABALIDIS, A. M., Effects of altitude and season on glandular hairs and leaf structural traits of Nepeta nuda L., Botanical Studies. 2008, 49, 363-372.

[12]. Pădure, I.M., Chorological and ecological aspects of Nepeta nuda L. ssp. nuda (syn. N. pannonica L.) from Lamiaceae-Nepetoideae in Romania, Analele ştiinţifice ale Universităţii “Al. I. Cuza”. 2004, Tomul L, s. II a. Biologie vegetală, 65-70.

[13]. Malenčić, D.; Máthé, I.; Veres, K.; P Boža, P., Chemical composition of essential oil of Nepeta nuda L. 1753 (Syn. Nepeta pannonica L. 1753) from the Pannonian plain, Planta Medica. 2008, 74 PI32, DOI: $10.1055 / \mathrm{s}-0028-1084940$

[14]. Gkinis, G.; Bozin, B.; Mimica-Dukic, N.; Tzakou, O., 2010. Antioxidant activity of Nepeta nuda L. ssp. nuda essential oil rich in nepetalactones from Greece. Journal of medicinal food. 2010, 13, 1176-81.

[15]. Kilic, O.; Hayta, S.; Bagci, E., Chemical Composition of Essential Oil of Nepeta nuda L. subsp. nuda (Lamiaceae) from Turkey, Asian Journal of Chemistry. 2011, 23(6), 2788-2790.

[16]. Ali, T.; Javan, M.; Sonboli, A.; Semnanian, S., Evaluation of the antinociceptive and antiinflammatory effects of essential oil of Nepeta pogonosperma Jamzad et Assadi in rats, DARU Journal of Pharmaceutical Sciences. 2012, 20:48 http://www.darujps.com/content/20/1/48

[17]. Sharma, A.; Cannoo, D. S., Phytochemical composition of essential oils isolated from different species of genus Nepeta of Labiatae family: A review, Pharmacophore. 2013, 4(6), 181-211.

[18]. Kobaisy, M.; Tellez, M. R.; Dayan, F. E.; Mamonov, L. K.; Mukanova, G. S.; Sitpaeva, G. T.; Gemejieva, N. G, Composition and Phytotoxic Activity of Nepeta pannonica L. Essential Oil. Journal of Essential Oil Research. 2005, 17(6), 704.

[19]. Eom, S.H.;Yang, H.S.; Weston, L.A., An evaluation of the allelopathic potential of selected perennial groundcovers: foliar volatiles of catmint (Nepeta $\mathrm{x}$ faassenii) inhibit seedling growth, $J$ Chem Ecol. 2006, 32(8), 1835-48.

[20]. Mancini, E.; Arnold, N. A.; De Feo, V.; Formisano, C.; Rigano, D.; Piozzi, F.; Senatore, F., Phytotoxic effects of essential oils of Nepeta curviflora Boiss. and Nepeta nuda L. subsp. albiflora growing wild in Lebanon, Journal of Plant Interactions. 2009, 4, 253-259.

[21]. Mutlu, S.; Atici, O; Esim, N.; Mete, E., Essential oils of catmint (Nepeta meyeri Benth.) induce oxidative stress in early seedlings of various weed species, Acta Physiol Plant. 2011, 33, 943-951.

[22]. Kekec, G.; Mutlu, S.; Alpsoy, L.; Sakcali, M S.; Atici, O., Genotoxic effects of catmint (Nepeta meyeri Benth.) essential oils on some weed and crop plants. Toxicology and Industrial Health. 2012, 29(6), 504-513.

50 
[23]. Bozari, S.; Agar, G.; Aksakal, O.; Erturk, F.A.; Yanmis, D., Determination of chemical composition and genotoxic effects of essential oil obtained from Nepeta nuda on Zea mays seedlings, Toxicology and industrial health. 2013, 29(4), 339-48.

[24]. Živković, J.M.N., Antioxidative, antimicrobial and allelopathic effects of three endemic Nepeta species (Lamiaceae) Doctoral Dissertation. University of Belgrade, Faculty of biology. 2013.

[25]. Mutlu, S.; Atici, O., Allelopathic effect of Nepeta meyeri Benth. extracts on seed germination and seedling growth of some crop plants, Acta Physiol Plant. 2009, 31, 89-93.

[26]. Babaahmadi, H.; Ghanbari, A.; Asadi, G.; Emami, M.K., Allelopathic Effect from some Medicinal Plants on Germination of Alyssum hirsutum and Amaranthus retroflexus. International Journal of Agronomy and Plant Production. 2013, 4(12), 3344-3347.

[27]. Todorov, D.; Shishkova, K.; Dragolova, D.; Hinkov, A.; Kapchina-Toteva, V.; Shishkov, S., Antiviral activity of medicinal plant Nepeta nuda. Biotechnology \& Biotechnological Equipment. 2015, 29(S1), 39-43.

[28]. Assyov, B.; Petrova, A.; Dimitrov, D.; Vassilev, R., Conspectus of the Bulgarian vascular flora. Distribution maps and floristic elements, Fourth revised and enlarged edition, Sofia, 2012.

[29]. Islam, A.K.M.M.; Kato-Noguchi, H., Allelopathic Potentiality of Medicinal Plant Leucas aspera, International Journal of Sustainable Agriculture. 2012, 4(1), 01-07.

[30. Kakati, B.; Baruah, A., Allelopathic Effect of Aqueous Extract of Some Medicinal Plants on Seed Germination and Seedling Length of Mung Bean (Vigna radiata (L.) Wilczek.), Indian Journal of Plant Sciences. 2013, 2, 8-11.

[31]. Verma, S.K.; Kumar, S.; Pandey, V.; Verma, R.K.; Patra, D., Phytotoxic Effects of Sweet Basil (Ocimum basilicum L.) Extracts on Germination and Seedling Growth of Commercial Crop Plants, European Journal of Experimental Biology. 2012, 2, 2310-2316.

[32]. Elisante, F.; Tarimo, M.T.; Ndakidemi, P.A., Allelopathic Effect of Seed and Leaf Aqueous Extracts of Datura stramonium on Leaf Chlorophyll Content, Shoot and Root Elongation of Cenchrus ciliaris and Neonotonia wightii, American Journal of Plant Sciences. 2013, 4, 2332-2339.

[33]. Keshavarzi, M. H. B.; Shakouri, M. J.; Saman, P.G.; Porkareh, M.H.; Koorgol, R.; Khosravi, E., Effect of Allelopathic Activity of Annual Wormwood on Seed Germination and Seedling Growth of Brassica napus L., Annals of Biological Research, 2011, 2(3), 529-532.

[34]. Sarkar, E.; Chatterjee, S.N.; Chakraborty, P., Allelopathic Effect of Cassia tora on Seed Germination and growth of Mustard, Turkish Journal of Botany. 2012, 36(5), 488-494.

[35]. Nishida, N.; Tamotsu, S.; Nagata, N.; Saito, C.; Sakai, A., Allelopathic Effects of Volatile Monoterpenoids Produced by Salvia leucophylla: Inhibition of Cell Proliferation and DNA Synthesis in the Root Apical Meristem of Brassica campestris Seedlings, Journal of Chemical Ecology. 2005, 31(5), 1187-1203.

[36]. Namkeleja, H.S.; Tarimo, M.T.; Ndakidemi, P.A., Allelopathic Effect of Aqueous Extract of Argemone mexicana $\mathrm{L}$ on Germination and Growth of Brachiaria dictyoneura $\mathrm{L}$ and Clitoria ternatea L., American Journal of Plant Sciences. 2013, 4, 2138-2147.

[37]. Kaymak, F.; Muranli, F.D.G., The Genotoxic Effects of Logran on Hordeum vulgare L. and Triticum aestivum L., Acta Biologica Hungarica. 2006, 57, 71-80.

[38]. Tanveer, A.; Rehman, A.; Javaid, A.M.; Abbas, R.N.; Sibtain, M.; Ahmad, A.U.H.; Ibin-I-Zamir, M.S.; Chaudhary, K.M.; Aziz, A., Allelopathic Potential of Euphorbia helioscopia L. against Wheat (Triticum aestivum L.), Chickpea (Cicer arietinum L.) and Lentil (Lens culinaris Medic.), Turkish Journal of Agriculture and Forestry. 2010, 34, 75-81. 